\title{
PROSES PELAKSANAAN FUNGSI ADMINISTRASI PERSONALIA LEMBAGA PENDIDIKAN
}

\author{
Muhammad Maulana \\ Program Studi Pendidikan IPS \\ Fakultas Keguruan dan Ilmu Pendidikan \\ Universitas Lambung Mangkurat \\ Banjarmasin \\ Email: 2010128210006@mhs.ulm.ac.id
}

\begin{abstract}
Abstrak
Pendidikan suatu wadah yang mana memiliki aktivitas usaha dalam menumbuhkan akan mengembangkan potensi dasar manusia serta kelompok, dengan memperoleh ilmu untuk hasil baik serta prestasi, pendidikan menjadikan suatu pandangan yang mana harus dikembangkan secara efektif. Administrasi dalam kelembagaan atau instansi sudah sering di dengar katanya, administrasi suatu faktor yang dapat diartikan sangat penting dalam keadaan aturan setiap kegiatan untuk majunya suatu instansi. penelitian kualitatif pada dasarnya merupakan penelitian yang berdasarkan studi literatur. penelitian kualitatif ini dengan mencari studi perpustakan mengumpulkan jurnal, dokumen, serta skripsi yang berkaitan dalam Administrasi Personalia Lembaga Pendidikan yang berdasarkan pada penulisan artikel ini, kemudian dikaitkan dengan Penelitian ini mendeskripsikan hasil paparan dari jurnal, buku serta refrensi lainnya, untuk mengetahui kaitannya proses pelaksanaan Administrasi Personalia dalam lembaga pendidikan tersebut.
\end{abstract}

Keywords : Administrasi Personalia, Lembaga Pendidikan

\section{Pendahuluan}

Pendidikan suatu wadah yang mana memiliki aktivitas serta usaha dalam menumbuhkan akan mengembangkan potensi dasar manusia serta kelompok, dengan memperoleh ilmu untuk hasil baik serta prestasi, pendidikan menjadikan suatu pandangan yang mana harus dikembangkan secara efektif untuk peradaban generasi proses pendidikan. Rahman, A. M., Mutiani, M., \& Putra, M. A. H. (2019). dalam kehidupan manusia sebagai kebutuhan yang sangat penting dan harus dipenuhi untuk mencapai sebuah kehidupan berbangsa dan memiliki moral dan etika manusia Afriansyah, H. (2019). agar mencapai kehidupan dalam keberhasilan berorganiasi serta terciptanya hidup berkelompok dalam hal pendidikan harus mampu menghasilkan lulusan yang berkualitas untuk menghasilkan upaya daya saing sesuai dengan kualitas nasional dan standar internasional dalam pendidikan harus menciptakan lulusan dalam menguasai hard skills dan soft skill sehingga bisa dapat bersaing 
untuk bisa mencari lapangan pekerjaan pada tingkat local nasional maupun global, upaya peningkatan dalam pendidikan harus disertai pembelajaran untuk mengharapkan kemajuan secara terus menerus semakin baik sehingga dalam konteks pendidikan menimbulkan kualitas yang sempurna.

Manajemen suatu ilmu yang membentuk sebuah proses menjalin kerja sama antara individu dan kelompok, disertakan dalam mencapai tujuan beorganisasi bertujuan menjadikan aktivitas manejerial, Fuad, M. (2019). serta manajemen dalam artinya sempit dalam penyusunan serta pencatataan informasi sebuah harga secara rinci dan sistematis untuk terlaksanakannya sebagai penyedian keterangan yang memudahkan memperoleh kembali keseluruhan pada hubungan satu dan lainnya. Rahman, A. M., Mutiani, M., \& Putra, M. A. H. (2019). Manajemen memberikan ruang lingkup yang berisikan tentang administrasi dalam kelembagaan organisasi dalam instansi. Manajemen dalam dunia Pendidikan yang beperan paling utaman dan sangat penting pada Lembaga yang bemuatan dengan Pendidikan secara non firmal dan formal pada sebuah Lembaga Pendidikan ini

Akitivitas yang mendasar untuk berkenaan denga semua hal Pendidikan sudah layaknya dikelola secara baik, sebab maka jika tidak organisasi Pendidikan yang sulit berjalan secara efektif, Rahman, A. M., Mutiani, M., \& Putra, M. A. H. (2019). pada dasarnya untuk menunjukan bahwa personalia salah satu faktor berkatian dengan personalia dan sumber manusia tertuju dalam proses Pendidikan seperti para tenanga pendidik dalam admnisitrasi, administrasi dalam proses suatu pelakasanaan pada kelembagaan atau instansi sudah sering di dengar katanya, administrasi suatu faktor yang dapat diartikan sangat penting dalam keadaan aturan setiap kegiatan untuk majunya suatu instansi. Administrasi sangat bertujuan penting dalam mempersiapkan kondisi segala proses pembelajaraan bagi Pendidikan, Paputungan, N. (2020). dan pengajaran secara langsung dan baik, untuk menunjukkan peningkatan yang diperlukan dan proses sempurna penyelenggaraan pada dasar system Pendidikan yang menyesuaikaan dengan adanya kebutuhan dan teknologi dari penyediaan saranadan pransarana prosessuatu Pendidikan yang memadai dalam tujuan Pendidikan kualitas manusia tanah air ini. Jadi Tujuan penulisan artikel ini membahas tentang untuk mengetahui kaitannya proses pelaksanaan Administrasi Personalia dalam lembaga pendidikan tersebut.

\section{Metode}


Pada penulisan Aritikel ini memakai penelitian kualitatif. dimana artikel disajikan secara deskriptif dan penelitian kualitatif pada dasarnya merupakan penelitian yang berdasarkan studi literatur. penelitian kualitatif ini dengan mencari studi perpustakan mengumpulkan jurnal, dokumen, serta skripsi yang berkaitan dalam Administrasi Personalia Lembaga Pendidikan yang berdasarkan pada penulisan artikel ini, kemudian dikaitkan dengan Penelitian ini mendeskripsikan hasil paparan dari jurnal, buku serta refrensi lainnya, untuk mengetahui kaitannya proses pelaksanaan Administrasi Personalia dalam lembaga pendidikan tersebut.

\section{Pembahasan}

Administrasi memiliki penerapan ilmu dalam dunia Pendidikan untuk pembinaan, pengendaliaan dalam pengembangan dasar usaha yang sebagai praktek sebuah Pendidikan, proses kegiatan akan pengendalian usaha dalam bentuk kerja sama dalam proses sejumlah orang atau kelompok yang memiliki dasar dalam kaidah tujuan Pendidikan dengan secara sistematis. Paputungan, N. (2020). Untuk diselenggarakannya proses akan Pendidikan dalam lingkungan hidup, yang paling utama dalam lembaga Pendidikan yang formal untuk melaksanakan opresional sebuah Pendidikan dalam kegiatan pengopresional menjadikan akan kegiatan secara edukatif yang mana seperti kegiatan belajar mengajar untuk bimbingan dan penyuluhan dan lainnya, pada dasar kaitannya dalam mampu untuk pengendalian akan sebuah kemampuan kegiatan secara serentak dengan operasional yang begerak dengan terarah dan tertuju dalam Pendidikan yang meunggulkan wujud efesiensi dan efektifitas.

Administrasi personalia sebuah arti yang memiliki semua anggota yang dikerjakan untuk kepentingan dasar akan organisasi dalam proses pencapai sebuah adanya tujuan yang mana isi sudah ditentukan dalam personalia ini mencakup organisasi Pendidikan para guru, pegawai, wakil peserta didik atau murid serta alumni kelulusan, maneger pendidikan juga termasuk. dalam personalia yang sebut personil pada dasarnya orang yang melakukan suatu tugas dalam pencapaian sebuah tujuan Pendidikan disebuah Lembaga dibatasi dengan sebutan pegawai, Meilina, S. (2020). karena itu personil Lembaga akan menentukan saja meliputi pada unsur guru yang mana guru disebut tenaga edukatif serta karyawaan sebagai tenanga admnisitrativenya. Admnisitrasi personali ini merencanakan akan sebua usaha secara nyata dan sunguh-sungguha dalam prinsip pembinaan dalam tindak lanjut para pegawagai sekolah yang mana dapat membantu untuk menunjang akan kegiataan sekolah, 
Proses dalam pelaksanaan sebagai fungsi dari Administrasi personalia dalam konsep untuk mencapai Lembaga Pendidikan bermutu dengan secara garis besarnya memiliki komponen pada admnisitrasi personil ini dalam ruang lingkup Pendidikan yang yaitu kurikulum, sarana prasarana Pendidikan, Meilina, S. (2020). sebagai admnistrasi siswa, sekolah dan masyarakat. Administrasi personalia sendiri yang mencakup pada perencanaa pegawai, pembinaan dalam pengembangan pegawai, promise dalam mutasi, pengadaan pegawai, pemberhentian pegawai dalam kompensasi penilaiaan untuk para pegawai. tujuan dari pada itu untuk meningkatkan akan mutu Pendidikan pada sekolah yang bertujuan untuk mutu kelulusan sebagai hal yang sulit dalam penghasilan sekolah untk mencari lulusan bermutu, pada dasarnya melalui proses bermutu begitu juga dengan proses akan Pendidikan jika tidak di dukung oleh administrator, guru, konselor dan sera tata usaha yang diperlukan bermutu dan professional.

Peran serta fungsi personalia dalam suatu organinasi termasuk sekolah, namun personalia dalam Lembaga Pendidikan untuk mengoptimalkan pada pengelolaan dengan baik serta pimpinan Lembaga Pendidikan mempunyai peranan sangat sentral dalam pengelolaan personalia Lembaga, yang mana pada dasarnya sangat penting jika pimpinan untuk mencerna seta menerapkan pengelolaan personalia baik sehingga tujuan Pendidikan dapat dicapai berjalan dasar dan tujuan serta fungsi administrasi personalia Lembaga Pendidikan berhasil akan baik apabila didasari dengan atas dasar yang sangat tepat untuk menyatakan suatu kebenaran secara fundamental dapat di gunakan sebagai landasan untuk pedoman betindak dalam masyarakat yang memiliki.

Prinsip efesiensi yang mana prinsip ini menjadikan seorang admnistrasi personalia dapat berhasil dalam mendapatkan tugas yang mencapai efesien menggunakan sumber tenaga dana dan fasilitas, Prinsip pengelolaan merencanakan admnistrasi akan memperoleh tujuan hasil ynag baik dan bagus melalui orang dengan jalanya melakukan pekerjaan administrasi untuk supaya terencana, mengorganisasikan, mengarahkan dan mengontrol, prinsip pengutamaan tugas pengelolaaan, Meilina, S. (2020). yang disertai akan pekerjaan manajemen dan kooperatif dalam waktu yang sama seorang admnistrasi memberikan prioritas pertama pada pekeerjaan yang harus operatif, admnistrastor harus mampu menjauhi kecenderungan yang buruk, sebab terlalu sibuk dengan tugas yang operatif, maka pekerjaan yang mana pengelolaan jadi tak terurus, jadi prinsip ini menjadi ciri khas dalam terbang tinggi dan rendah 
suatu taraf pengorganisasian, semakin tinggi taraf personalia Lembaga bagi pendidikan maka akan dilihat dari makin sebanyaknya pekerjaan operatif harus dilakukan.

Dalam Proses pelaksanaan fungsi administrasi personalia terdapat Ruang lingkup nya sendiri dalam penyusunan terdapat dalam hal perencanaan pegawai (personnel planning), pengadaaan pegawai (recruitment), pembiayaan atau pengembangan pegawai (personnel development), promosi dan mutasi, pemberhentian pegawai, pensiun, dan kesejahteraan pegawai. Sehingga proses dalam pelaksanaan fungsi administrasi peronalia mendapatkan ruang lingkup di lembaga pendididkan akan sebagai kegiatan-kegiatan dalam meliputi administrasi personel untuk penyiapan atau pengadaan pegawai, penataan, penempatan atau pengangkatan pegawai atau personel, kenaikan pangkat, ujian dalam angka kredit bagi kenaikan jabatan fungsional guru, pembinaan pegawai negeri sipil (PNS), Afriansyah, H. (2019). pengembangan personel, dan penilaian pelaksanaan pekerjaan PNS.

\section{Simpulan}

Pendidikan suatu wadah yang mana memiliki aktivitas serta usaha dalam menumbuhkan akan mengembangkan potensi dasar manusia serta kelompok, dengan memperoleh ilmu untuk hasil baik serta prestasi. Administrasi memiliki penerapan ilmu dalam dunia Pendidikan untuk pembinaan, pengendaliaan dalam pengembangan dasar usaha yang sebagai praktek sebuah Pendidikan, proses kegiatan akan pengendalian usaha dalam bentuk kerja sama dalam proses sejumlah orang atau kelompok yang memiliki dasar dalam kaidah tujuan Pendidikan dengan secara sistematis.

Administrasi personalia sebuah arti yang memiliki semua anggota yang dikerjakan untuk kepentingan dasar akan organisasi dalam proses pencapai sebuah adanya tujuan yang mana isi sudah ditentukan dalam personalia ini mencakup organisasi Pendidikan para guru, pegawai, wakil peserta didik atau murid serta alumni kelulusan, maneger pendidikan juga termasuk. Proses pelaksanaan fungsi administrasi personalia terdapat Ruang lingkup nya sendiri dalam penyusunan terdapat dalam hal perencanaan pegawai/personnel planning, pengadaaan pegawai/recruitment, pembiayaan atau pengembangan pegawai/personnel development, promosi dan mutasi, pemberhentian pegawai, pensiun, dan kesejahteraan pegawai.

\section{Daftar Pustaka}

Abbas, E. W. (2018). Penguatan Pendidikan IPS Di Tengah Isu-Isu Global. Program Studi Pendidikan IPS FKIP ULM. 
Afriansyah, H. (2019). Administrasi Pendidikan di Indonesia.

Ahya, R. R., Syaharuddin, S., \& Rahman, A. M. (2020). The Caring Attitudes for Environment of Lanting Householders as a Learning Resource on Social Studies. The Innovation of Social Studies Journal, 2(1), 66-74.

Fuad, M. (2019). Manajemen Personalia Lembaga Pendidikan: MA Darul Ihsan Samarinda dan SMA YPM Diponogoro Tenggarong Seberang. SYAMIL: Jurnal Pendidikan Agama Islam (Journal of Islamic Education), 7(1), 27-38.

Meilina, S. (2020). Implementasi Pengelolaan Administrasi Personalia Pada Pt. Ganda Prabu Nusantara Pekanbaru. Ensiklopedia Sosial Review, 2(3), 197-207.

Paputungan, n. (2020). Pelaksanaan fungsi administrasi personalia pendidikan di madrasah tsanawiyah negeri 1 bolaang mongondo (doctoral dissertation, iain manado).

Rahman, A. M., Mutiani, M., \& Putra, M. A. H. (2019). Pengaruh kompetensi pedagogik dosen terhadap motivasi belajar mahasiswa pendidikan IPS. Jurnal Darussalam: Jurnal Pendidikan, Komunikasi dan Pemikiran Hukum Islam, 10(2), 375-387.

Sarbaini, S., ABBAS, E. W., Wahyu, W., \& SOFYAN, A. (2020). PENDIDIKAN KARAKTER.

Syaharuddin, S., Rahman, A. M., \& Fitriyani, R. (2019). Utilization Of Social Community as Learning Resources On Social Studies. The Kalimantan Social Studies Journal, 1(1), 1824.

Zainal, M. Suatu Analisis Terhadap Fungsi Administrasi. 